\title{
Predicting Non-performing Loans by Financial Ratios for Small and Medium Entities in Lebanon
}

\author{
Samih Antoine Azar ${ }^{1}$, Marybel Nasr ${ }^{1}$ \\ ${ }^{1}$ Faculty of Business Administration \& Economics, Haigazian University, Beirut, Lebanon \\ Correspondence: Samih Antoine Azar, Faculty of Business Administration \& Economics, Haigazian University, \\ Mexique Street, Kantari, Beirut, Lebanon
}

Received: May 29, 2015 Accepted: June 23, 2015 Online Published: July 1, 2015

doi:10.11114/bms.vli2.844

URL: http://dx.doi.org/10.11114/bms.v1i2.844

\begin{abstract}
This study examines the ability of financial ratios in predicting the financial state of small and medium entities (SME) in Lebanon. This financial state can be either one of well-performing loans or one of non-performing loans. An empirical study is conducted using a data analysis of the financial statements of 222 SMEs in Lebanon for the years 2011 and 2012, of which 187 have currently well-performing loans and 35 have currently non-performing loans. Altman Z-scores are calculated, independent samples t-tests are performed, and models are developed using the binary logistic regression. Empirical evidence shows that the Altman Z-scores are able to predict well the solvent state of SMEs having well-performing loans, but are unable to predict accurately the bankruptcy state of the SMEs having non-performing loans. The independent samples t-tests revealed that five financial ratios are statistically significantly different between SMEs having well-performing loans and those having non-performing loans. Finally, a logistic regression model is developed for each year under study with limited success. In all cases accuracy results are inferred showing the percentage of companies that are accurately classified for being solvent and bankrupt, in addition to the two standard measures of error: the Type I errors and the Type II errors. Although a high accuracy is achieved in correctly classifying non-distressed and distressed firms, the Type I errors are in general relatively large. By contrast the Type II errors are in general relatively low.
\end{abstract}

Keywords: failure prediction, Altman Z-score models, financial ratios, two-samples independent t-tests, binary logistic regression, prediction accuracy, Type I and Type II errors

\section{Introduction}

The banking sector, the backbone of every economy, faces many risks among which one can mention systemic risk, market risk, operational risk, credit risk, liquidity risk and other essentially idiosyncratic risks. Each risk should be managed and its negative effects should be minimized. Credit risk is the risk that the bank is unable to collect the interest and/or the principal of a loan on a predetermined date. Credit risk is directly related to the bankruptcy risk of the companies which constitute the bank's borrowers. The ability to accurately predict if a company will go bankrupt is not only important to every bank, but also to potential investors, to existing shareholders, to clients and even to the employees dealing with the company under scrutiny. In this study, the aim is to evaluate the ability of financial ratios to predict the failure or solvency of a given firm. The definition of bankruptcy is the incapability of companies to fulfill their part in a financial banking transaction or, in other words, their incapacity to repay in time the borrowed amounts according to the conditions established in the loan agreement.

In Lebanon, the financial definition of bankruptcy is applied, and this according to the Central Bank's differentiation of the well-performing and non-performing loans in its Basic Circular No. 58, where the differentiation of the two categories is based upon characteristics such as the repayment of a loan, account movement at the bank, financial state of the borrower, legal state of the borrower, the situation of the client with other banks etc. The criterion that is the most relevant is the repayment of a loan: borrowers having well-performing loans repay their dues on time or with delays not exceeding 90 days, whereas borrowers having non-performing loans are classified as such when the delays in repayment exceed 90 days.

This thesis will focus on bankruptcy prediction of Small and Medium Entities (SME) in Lebanon through financials ratios. In other words the thesis will test if the financial ratios of a company can accurately predict if a SME is in the 
well- performing loans or in the non-performing loans category. The Central bank's definition of the loans to Small and Medium Entities portfolio is included in the Central Bank's Basic Circular No. 115 and is as follows: a) loans granted to liberal professions such as doctors, engineers and lawyers in order to finance their professional activities, b) loans granted to sole proprietorships or to corporations (general partnerships, limited partnerships, jointly-owned companies, joint-stock companies including holdings, partnerships limited by shares, limited liability companies and offshore companies), the annual turnover of which does not exceed the equivalent of USD 5 million.

The paper tests whether the financial ratios of a company can accurately predict if this company is in the well-performing loans category or the non-performing loans category. Three procedures will be used in this context: (1) application of bankruptcy prediction models on past financial statements of these SMEs, (2) carrying out independent two samples t-tests on the financial ratios of the first category of firms relative to those of the second category, and (3) estimation of models using the procedure of binary logistic regression.

The bankruptcy prediction models, or scoring methods, were developed with the use of statistical methods in order to analyze the financial ratios of firms and their ability to forecast financial bankruptcy. The bankruptcy prediction models that are selected from the literature are the Altman Z'-score and the Altman Z'-score (Altman, 2002). These two models were chosen among several other models because they are technically applicable to the Lebanese financial statements. Altman's original Z-score model, which was developed in 1968, was meant to be applied on manufacturing companies with a capital of over \$ 1 million, and it contains the ratio "market value of equity over the book value of total debt". But since in Lebanon there is no stock exchange market for private companies, then the formula cannot be of use. Altman's Z'-score and Z'-score were later derived from the original Z-score, each one with an attuned formula to a specific type of companies. The Z'-score is meant to be applied on privately-held manufacturing firms and the Z'-score is meant for both public and private non-manufacturing firms. See Appendix A for details on these two Altman Z-scores.

The second procedure consists of performing independent two samples t-tests on each of the 22 financial ratios taken from and found in the literature. See Appendix B for a list of these ratios. These tests serve to indicate whether there is a significant difference between the ratios of SMEs that have well-performing loans and those of SMEs that have non-performing loans.

The third procedure consists of estimating models based on the sample under study using the binary logistic regression. The regression model is constituted of independent variables and their related coefficients, which indicate the change each variable causes to the odds ratio of the tested bankruptcy event happening or not. The dependent variable is thus the odds ratio, which is defined as the ratio of the probability of not going under on the probability of bankruptcy. The variables selected to be the independent variables are the financial ratios that prove to have the most predictive ability of bankruptcy. The dependent variable is categorical and classifies a given company with a well-performing loan by the number 1 , and a company with a non-performing loan by the number zero.

Therefore the purpose of this study is to identify which model proves to be the most accurate in predicting default of SMEs in Lebanon. As such, if one or more models achieve high levels of prediction accuracy, the model(s) can be used by the Lebanese banks to make better credit granting decisions for new clients, or to better monitor the financial situation of existing borrowers. The results can also be used as a warning sign to the businesses on the verge of bankruptcy, enabling the owners to adopt corrective measures and to avoid failure.

The paper is organized as follows. The next section, section 2, presents a survey of the literature. Section 3 discusses the research methodology. Section 4 is the empirical part and has three subsections corresponding to the three main procedures adopted to differentiate between firms with well-performing loans and those with non-performing loans. The final section, section 5, summarizes and concludes.

\section{Literature Review}

The first part of the literature review discusses the papers which employ the Altman Z-score models. To apply the Z-score method, a set of companies, formed of two distinct groups, must be under study: a group of companies facing financial difficulties and a group of companies free of financial problems. A set of ratios is established for each group, and the best linear combination of ratios is determined. The goal is to combine the ratios in the best way possible to differentiate between the two groups of companies. The discriminant analysis is then applied and the Z-score is obtained for each firm. The differentiation between solvent and insolvent companies is determined by the Z-score value (Bordeianu et al., 2011). These researchers tested the Altman model along with three other bankruptcy prediction models, for the years 2008, 2009, and 2010 using a dataset of commercial, cooperative, and savings banks for the Organization for Economic Cooperation and Development (OECD) countries covering the period 1994 to 2008. The results of the different models for each year were quite compatible and comparable.

Alkhatib and Al Bzour (2011) seek to identify the predictive ability of both Altman and Kida models in giving an early 
sign of company bankruptcy, and also to find out which of the two models is more appropriate in predicting bankruptcy of a sample of Jordanian listed companies for the period between 1990 to 2006 for each year of the five years prior to liquidation. Results show that a Z-score higher than 0.38 is considered to be a good sign for a successful firm and a $\mathrm{Z}$-score less than 0.38 indicates serious financial problems. The results provide evidence in favor of the hypothesis that there is no statistically significant difference between the Altman and Kida models for predicting bankruptcy.

Strobel (2011) aims to analyze and evaluate the methods used to measure the systematic soundness of the banking sector. After refinement of the data, the remaining sample included data for 11,300 banks with an average of 10.7 years of observations. Calculations of descriptive statistics for many different aggregate $\mathrm{Z}$-score measures (aggregate, mean, median, weighted mean, weighted median, first percentile, and weighted first percentile) are made. The results show that (1) the aggregated data-based measure gives results that are more similar to the ones obtained by the weighted mean-based and median-based measures than for the un-weighted ones, (2) the mean-based and the median-based measures show high correlations in their weighted and un-weighted forms; they are thus very similar in terms of how they assess relative systemic soundness, and (3) weighted and un-weighted measures have slightly different implications regarding the ranking of systemic soundness.

$\mathrm{Li}$ (2012) examines the prediction of corporate failures in the U.S. during 2008-2011. Three prediction models are examined: Altman's original Z-score model, a re-estimated Z-score model and a re-estimated model with an added variable. Many studies conclude that the Altman's Z-score is effective in predicting corporate financial distress (e.g. Gerantonis, et al., 2009; Lugovskaya, 2010; Wang and Campbell, 2010; and Li and Rahgozar, 2012). However the Z-score has its limitations. First, it uses unadjusted accounting data, data from relatively small firms, and old data. There is evidence that the Z-score coefficients should be re-estimated for the prediction of corporate distress involving different time periods or different industries (Grice and Ingram, 2001). Second, four of the ratios used are accounting-based, which are not forward looking. Third, the only ratio in Altman's original model that is market-based and forward looking is the market value of equity over total liabilities. Furthermore, it doesn't include a measure of asset volatility, which determines the probability that the value of a firm's assets will decline to an extent that it is unable to pay its debts (Hillegeist et al., 2004).

Although the original Z-score model was developed for manufacturing firms, it performs equally well in predicting bankruptcy for non-manufacturing companies. The model with only one variable, the market value of equity over total liabilities, appears to have the highest bankruptcy predicting power. Although it is a widespread criticism of the Z-score model, total asset variability does not appear to be a significant factor for bankruptcy prediction. On the other hand, there's evidence that asset volatility is a significant factor for the bankruptcy prediction of manufacturing firms ( $\mathrm{Li}$ and Rahgozar, 2011).

The primary objective of Li and Rahgozar (2011) is to re-examine the accuracy of the original Z-score in predicting corporate failures in the U.S. from 2000 to 2010. Altman's original model predicts that firms with Z-scores above 3 are unlikely to file for bankruptcy, and firms with Z-scores below 1.81 are likely to fail. Z-scores between 3 and 1.81 are considered in a "grey" area. The results reveal that out of 252 firms, the number and percentage of accurate bankruptcy predictions applying one and two-year Z-scores are $156(61.90 \%)$ and $171(67.86 \%)$ respectively, while accurate prediction by averages of three and five years are 178 (70.63\%) and $194(76.98 \%)$. These estimates imply that observations of financial performance over a longer period (i.e., 5 years) could lead to better predictions of financial distress than a shorter period like one or two years.

The accuracy of the Z'-score in predicting bankruptcy in New Zealand is studied in 2012 through a research note (Samkin et. al., 2012). Some limitations of failure prediction models are identified, such as the failure to take into consideration non-financial factors. Another limitation is the fact that a single model is not suitable for predicting business failures across different types of firms and different industries. In addition, accuracy levels of failure prediction models are dependent on the model used and the period of time prior to failure.

Failure prediction is also tested through a case study of Jordan (Alareeni and Branson, 2013). More specifically, the authors aim to test the generalizability of the two models being the Altman Z-score and the Altman Z"-score in the Jordanian environment. The sample tested consists of 71 failed and 71 non-failed companies. The financial statements (balance sheet and income statement) are gathered for three full years for each tested company. The Z-score is applied on industrial and service companies and the Z"-score is only applied on service firms. The original Altman Z-score proved to be generalizable in Jordan, where it is able to predict failed industrial companies. Both the Altman Z-score (1968) and the Altman Z"-score (1993) have low predictive abilities for service firms.

Other researchers from Latvia evaluate seven bankruptcy prediction models on Baltic companies (Berzkalne and Zelgalve, 2013). They test the Altman Z-score, the Altman Z'-score, the Altman Z"'-score, the Sorin-Voronova model, the Zmejewski model, the Fulmer model, and the Springate model. Type I error is identified as the misclassification of bankrupt firms as non-bankrupt, and Type II error is the misclassification of non-bankrupt firms as bankrupt. The 
following findings are drawn from the study. First, although the performance of bankruptcy prediction models is important, particularly during the changing economic conditions, it is uncertain whether any model is able to generate good results during economic downturns. Second, good outcomes are achieved by Altman Z' and Altman Z" models during the economic growth phase.

A study conducted on 89 bankrupt Italian companies (52 of the sample were manufacturing companies), which are subject to Extraordinary Administration, a bankruptcy filing chapter in Italy, applies the Z-score to the financial statements of Italian companies between 2000 and 2010 (Altman et al., 2013). The authors indicate that the model is not probabilistic but rather descriptive-comparative, meaning that it should be used as a warning device rather than as a definitive prediction tool. The Z"-score was chosen to be tested. The Z"-score is calculated for each of the 5 years before the declaration of bankruptcy, and the results showed that on average, over the whole five years prior to bankruptcy, in $72.3 \%$ of the cases (which increases to $77.8 \%$ if the results from year 5 from bankruptcy are excluded), the classifications of the indicator are correct. As for the control sample, more than $50 \%$ of the control sample's firms are classified inside the safe zone. This percentage remains relatively stable; noting that the average of firms in the safe zone drops from $51 \%$ in 2008 to nearly $49 \%$ in 2009, underlining the negative effects of the credit crisis on the Italian market in 2008. The authors concluded that Altman's Z"-score model can be applied to the Italian manufacturing context but with a few cautions.

The second part of the literature review presents the papers which identified the financial ratios that are significantly different between bankrupt and solvent companies, and some of these papers develop bankruptcy prediction models as well, using those same financial ratios as independent variables.

Kovács et al., (2011) chooses to study eighteen financial ratios. The sample consists of 3000 commercial banks (solvent and non-solvent) in Romania. Their financial statements are gathered for the period 1999-2008. For each year, the percentage of defaulted companies to the total number of companies tested is calculated. To identify the significant indicators of the solvency of companies, the 2-samples t-test method is selected. During the studied ten years, eight ratios proved to be statistically significantly different from each other.

Waszkowski (2011) aims also to develop models that can predict corporate bankruptcy, using the financial ratios of the subject company. The sample consists of 41 legally bankrupt companies and 41 healthy companies, and 15 financial ratios are selected to be tested for statistical difference. Two models using the logistic regression are developed and two models using the discriminant analysis are developed, and these models are tested on the initial sample, and then the results are validated on a sample of 16 companies ( 8 bankrupt, 8 healthy). The models using the logistic regression produce higher accuracy rates than the models using discriminant analysis, with results ranging from $88.89 \%$ to $94.4 \%$ accuracy (vs. 50\% to $89.02 \%$ accuracy for discriminant analysis models).

Sirirattanaphokun and Pattarathammas (2012) test the difference of 22 financial ratios when applied on 199 failed firms and 398 non-failed firms. After applying the test of equality of means, the 8 financial ratios that passed the tests are used to develop the two models, one using the multivariate discriminant analysis (MDA), and the other one using the binary logistic regression. The highest predictive accuracy is achieved by the logistic regression using only financial ratios, with an R- squared of $85.5 \%$ for the out-of-sample test.

Onofrei and Lupu (2014) create models using the multivariate discriminant analysis (MDA) and the logistic regression to assess the corporate bankruptcy prediction ability of financial ratios. The sample consists of 100 companies, 50 viable and 50 bankrupt. The financial statements of the companies are gathered for the years 2007 to 2011 . To select the independent variables of the models, fourteen financial indicators from 5 different categories (each category interested a specific group of stakeholders) are tested for statistical difference between the bankrupt companies and the viable companies. The means of each of the 14 financial indicators are calculated for the 2 groups (bankrupt and viable) for the years 2007 until 2011, and a cumulative result is also calculated for the three years 2009, 2010 and 2011. To select the indicators that best represent the information gathered for each year from the pool of 14 indicators, a Principal Component Analysis is used. Using the MDA, a model for each year is created, in addition to a model for the cumulative years 2009-2011. The same procedure is done using the logistic regression. The models are applied on the initial sample to conduct the a priori analysis. The cumulative function for the three years achieves the highest accuracy results (96\% for MDA and $84 \%$ for logistic regression). In the a posteriori analysis, which consists of applying the models to another sample of similar firms (total of 40 companies, 20 bankrupt and 20 viable), further reveals the accuracy of the cumulative function (95\% for MDA and $82 \%$ for logistic regression). The author concludes that the MDA is the best predictor for the Romanian market.

The third approach is to develop a customized model for the sample under study using significant financial ratios. In the literature review, two statistical methods are used: the binary logistic regression and the multivariate discriminant analysis. The former is preferable due to the fewer distributional assumptions needed, and due to the fact that the latter requires classifying firms in more than three different categories. 
Based on the above literature review, the paper is structured. Since all the papers specified that the most internationally tested models are the Altman models, yielding the highest levels of accuracy worldwide compared to other models, it is decided to apply Altman's Z-scores in Lebanon as a first approach. As already mentioned, the Altman Z'-score and Altman Z"-score are selected for their applicability on Lebanese companies, in contrast with the original Altman Z-score. For the second approach financial ratios in Lebanon are tested for statistical significance, as done by many papers in the literature review. The third approach is to estimate a customized logistic regression model using jointly significant financial ratios. Such a customized model may provide better accuracy levels because it is estimated directly from the data at hand.

\section{Research Methodology}

\subsection{Research Questions}

The purpose is to explore whether the solvency of the SMEs in Lebanon can be predicted solely by their financial ratios, through three different approaches, which are the following: to evaluate the bankruptcy prediction ability of the Altman Z'-score and the Altman Z"'score; to determine whether the financial ratios of defaulted SMEs and solvent SMEs are statistically significantly different from each other; and to determine if a logistic regression can accurately predict the solvency/insolvency classification. A model that can predict bankruptcy is the one that achieves high percentage of accuracy in the classification of both solvent companies and bankrupt companies, resulting in low Type I and Type II errors.

\subsection{Research Hypotheses}

The following research hypotheses are tested.

Hypothesis 1 - The Altman Z'-score and Z'-score can accurately predict the classification of performing and non-performing loans for SMEs in Lebanon.

Hypothesis 2 - There are significant differences between the financial ratios of SMEs subject to well-performing loans versus the SMEs subject to non-performing loans in Lebanon. There are 22 sub-hypotheses for Hypothesis 2, being one for each financial ratio tested. The significant ratios are the ones that register actual test $p$-values lower than $5 \%$ in the independent samples t-test.

Hypothesis 3 - The estimated model using the binary logistic regression can accurately predict the classification of well-performing loans and non-performing loans for SMEs in Lebanon.

\subsection{The Sample}

The financial statements of SMEs in Lebanon, being the balance sheet, the income statement and other statements, are extracted from the dataset of a large bank in Lebanon that prefers to remain anonymous. The sample size includes 222 SMEs, of which 187 are subject to well-performing loans and 35 subject to non-performing loans. From the total number of companies, 63 are manufacturing companies (being 7 subject to non-performing loans and 56 subject to well-performing loans) and 159 are non-manufacturing companies (being 28 subject to non-performing loans and 131 subject to well-performing loans). The relevant population is the one defined by all Lebanese SMEs that have borrowed from a Lebanese bank.

\subsection{Type I and Type II Error}

The Type I error is misclassifying insolvent companies as solvent. The Type II error is misclassifying the solvent companies as insolvent. In this case, the Type I error is the more dangerous, since it would lead to a defaulted loan because an actually insolvent company was classified as solvent and accordingly it was granted a loan on which it will default. In contrast, the Type II error is only a missed profitable opportunity, that of not lending to a financially healthy SME a loan that it will repay on time, because it was wrongly classified as bankrupt.

\section{Statistical Analysis}

\subsection{Altman's Z-scores}

Tables 1, 2, and 3 present the classification results for the Altman Z'-score, while Tables 4, 5, and 6 present the classification results for the Altman's Z"-score. Tables 1 and 4 deal with predictions for the year 2013 based on ratios in 2011. Tables 2 and 5 deal with predictions for the year 2013 based on ratios for the year 2012. And, finally, Tables 3 and 6 deal with predictions for the year 2013 based upon the average of the ratios of the years 2011 and 2012. 
Table 1. Altman Z'-score based on year 2011 for predictions of year 2013

\begin{tabular}{lllll}
\hline & Bankrupt & Solvent & Grey area & Total \\
\hline Bankrupt & $34.3 \%$ (no error) & $34.4 \%$ (Type I) & $31.3 \%$ & $100 \%$ \\
Solvent & $0.5 \%$ (Type II) & $67.4 \%$ (no error) & $32.1 \%$ & $100 \%$ \\
\hline
\end{tabular}

Table 2. Altman Z'-score based on year 2012 for predictions of year 2013

\begin{tabular}{lllll}
\hline & Bankrupt & Solvent & Grey area & Total \\
\hline Bankrupt & $34.3 \%$ (no error) & $31.4 \%$ (Type I) & $34.3 \%$ & $100 \%$ \\
Solvent & $2.1 \%$ (Type II) & $69 \%$ (no error) & $28.9 \%$ & $100 \%$ \\
\hline
\end{tabular}

Table 3. Altman Z'-score based on the averages of years 2011 and 2013 for predictions of year 2013

\begin{tabular}{lllll}
\hline & Bankrupt & Solvent & Grey area & Total \\
\hline Bankrupt & $40 \%$ (no error) & $31.4 \%$ (Type I) & $28.6 \%$ & $100 \%$ \\
Solvent & $1.8 \%$ (Type II) & $69.5 \%$ (no error) & $28.7 \%$ & $100 \%$ \\
\hline
\end{tabular}

The results in Tables 1, 2, and 3, using the Z'-score are quite similar. The accuracy of predicting a distressed firm ranges between $34.3 \%$ and $40 \%$. The accuracy of predicting non-distressed firms ranges between $67.4 \%$ and $69.5 \%$. The Type I errors are relatively large and range between $31.4 \%$ and $34.4 \%$. Type II errors are very small and range between $0.5 \%$ and $2.1 \%$. The grey areas do not depend on financial distress and range between $28.6 \%$ and $34.3 \%$.

The results in Tables 4, 5, and 6, using the Z" -score are also quite similar. The accuracy of predicting a distressed firm ranges between $25.7 \%$ and $40 \%$. The accuracy of predicting non-distressed firms ranges between $93 \%$ and $94.1 \%$, figures that are relatively high and are higher than the results with the Z'-score. The Type I errors are relatively larger than before and range between $48.6 \%$ and $57.1 \%$. Type II errors are very small and range between $1.6 \%$ and $2.1 \%$.The grey areas depend on financial distress and range between $11.4 \%$ and $22.9 \%$ for distressed firms and between $4.3 \%$ and $4.9 \%$ for non-distressed firms. In general the Altman Z"-score is more accurate and less misleading than the Altman Z'-score. However, this does not mean that the results are satisfactory. It is important to stress, as Altman himself did, that these Z-scores should be interpreted as indicators or as signs of alarm, and not as definite truths.

Table 4. Altman Z"-score based on the year 2011 for predictions of year 2013

\begin{tabular}{lllll}
\hline & Bankrupt & Solvent & Grey area & Total \\
\hline Bankrupt & $25.7 \%$ (no error) & $57.1 \%$ (Type I) & $17.2 \%$ & $100 \%$ \\
Solvent & $2.1 \%$ (Type II) & $93 \%$ (no error) & $4.9 \%$ & $100 \%$ \\
\hline
\end{tabular}

Table 5. Altman Z"-score based on the year 2012 for predictions of year 2013

\begin{tabular}{lllll}
\hline & Bankrupt & Solvent & Grey area & Total \\
\hline Bankrupt & $40 \%$ (no error) & $48.6 \%$ (Type I) & $11.4 \%$ & $100 \%$ \\
Solvent & $1.6 \%$ (Type II) & $93.6 \%$ (no error) & $4.8 \%$ & $100 \%$ \\
\hline
\end{tabular}

Table 6. Altman Z"-score based on the average of years 2011 and 2012 for predictions of year 2013

\begin{tabular}{|c|c|c|c|c|}
\hline & Bankrupt & Solvent & Grey area & Total \\
\hline Bankrupt & $25.7 \%$ (no error) & $51.4 \%$ (Type I) & $22.9 \%$ & $100 \%$ \\
\hline Solvent & $1.6 \%$ (Type II) & $94.1 \%$ (no error) & $4.3 \%$ & $100 \%$ \\
\hline
\end{tabular}

\subsection{Independent Samples T-tests}

The second step of this study is to determine which financial ratios of the 22 financial ratios tested, is individually significantly different between bankrupt and solvent Lebanese SMEs. The financial ratios that are significantly different are those that may be most predictive of the state of a company. These ratios are tested through the independent samples t-test, applied o the years 2011, 2012 and on the average of these two years. The test consists first of determining if equal variances are to be assumed or not, with $\mathrm{H} 0=$ variances between bankrupt and solvent companies are equal, and $\mathrm{H} 1$ = variances between bankrupt and solvent companies are not equal. If the p-value for this test is above 0.05 , then we fail to reject the null and equal variances are assumed. If the p-value is less than 0.05 , then we reject the null and unequal variances are assumed.

Based on the variances being equal or not, the p-value of each t-ratio is selected. The null hypothesis here is that the p-value of the ratio is greater than 0.05 , meaning that the ratio is the same for bankrupt and solvent companies while H1 is that the p-value is less than 0.05 , meaning that the ratio is significantly different for bankrupt and solvent companies. Since there are 22 financial ratios considered together with 3 data sets, for 2011, for 2012, and for the average of the two years, and since there are two tests per ratio corresponding to unequal and equal variances tests respectively, the total number of tests is 132 , and takes four single-spaced pages to report. For this reason only the results are given below.

These results show the following:

(a) The ratio of liabilities over equity is significantly different in 2011 .

(b) The ratio of current assets over total assets is significantly different in 2012. 
(c) The log of total assets is significantly different in 2012 and the average of the years 2011 and 2012.

(d) The ratio of liquid assets over current assets is significantly different in 2011, 2012 and the average of the years 2011 and 2012.

(e) The ratio of fixed assets over total assets is significantly different in 2012.

(f) The ratio of current assets over current liabilities is significantly different in 2012 and the average of the years 2011 and 2012.

(g) The ratio of total liabilities over total assets is significantly different in 2011, 2012 and the average of the years 2011 and 2012.

(h) The ratio of total equity over total assets is significantly different in 2011, 2012 and the average of the years 2011 and 2012.

(i) The ratio of sales over total liabilities is significantly different in 2011, 2012 and the average of the years 2011 and 2012.

(j) The ratio of working capital over total assets is significantly different in 2011, 2012 and the average of the years 2011 and 2012.

Since the ratios of current assets over total assets and fixed assets over total assets, and the ratios liabilities over assets and equity over total assets are complements, i.e. their sums are equal to unity then the significance of one of the ratios will certainly mean that the other ratio is also significant.

The independent samples t-test assumes that the variables of interest are normally distributed, although one can invoke the Central Limit Theorem if the sample is large enough. If one takes the total sample of entities eleven out of 66 ratios are found to be normally distributed. For the rest the null hypothesis of normality is rejected. If one takes only the entities with well-performing loans 3 ratios out of 66 are found to be normally distributed. Finally, if one takes the entities with non-performing loans 25 ratios out of 66 are found to be normally distributed. Therefore the assumption of normality is most often rejected. As mentioned above, especially for cases like this, the Central Limit Theorem is invoked.

\subsection{Logistic Regression Models}

The third procedure consists of developing a logistic regression model for each year under study, made of jointly significant ratios that can accurately predict the state of SMEs in Lebanon. The binary logistic regression is used on SPSS 20 and checked on EViews 8.1. The choice of using the binary logistic regression is to conform to the literature on the subject, as most researchers estimate a binary logistic regression. Moreover there is some evidence from the literature that the binary logistic regression provides better empirical results. The sample is divided into two: solvent entities assigned the value 1 and bankrupt entities assigned the value zero. The independent variables are a sample from the 22 financial ratios. Stepwise regression is implemented. The significance of the models, the meaning of the ratios, and the accuracy levels are discussed.

\subsubsection{Logistic Regression Based on Ratios for the Year 2011}

For the year 2011, two ratios proved to be jointly significant: the book value of equity over the book value of liabilities, with a coefficient of 0.320 and a p-value for the Wald test of 0.003 , and the working capital over total assets, with a coefficient of 2.256, and a p-value for the Wald test of 0.010. See Appendix C, panel A.

An increase of the ratio of equity over liabilities by 1 unit increases the odds that the company will be solvent by the exponential of 0.32, being 1.377. This means that the higher the equity of an SME relatively to its debts, the higher the odds ratio that it will be in good financial health.

An increase of the ratio working capital over total assets by 1 unit increases the odds ratio that the company will be solvent by the exponential of 2.256 , being 9.549 . This indicates that the higher the working capital relatively to total assets, the better off the SME will be. The working capital is defined as current assets minus current liabilities.

Three bankrupt companies out of the total 35 bankrupt companies are accurately classified as bankrupt (8.6\%).The remaining 32 are misclassified as solvent (this is the Type I error, being 91.4\%). A total of 186 solvent companies of the total of 187 solvent companies are accurately classified as solvent (99.5\%). The remaining SMEs are misclassified as bankrupt. The overall accuracy percentage is $85.1 \%(8.6 * 35+99.5 * 187) / 222$. See Table 7 . The R-Square is 0.238 . This signifies that $23.8 \%$ of the variation in the dependent variable is explained by the variation in the independent variables.

Table 7. Classification of the results of the logistic regression using ratios for the year 2011

\begin{tabular}{llll}
\hline & Bankrupt & Non-bankrupt & Total \\
\hline Bankrupt & $8.6 \%$ (no error) & $91.4 \%$ (Type I) & $100 \%$ \\
Non-bankrupt & $0.5 \%$ (Type II) & $99.5 \%$ (no error) & $100 \%$ \\
\hline
\end{tabular}




\subsubsection{Logistic Regression Based on Ratios for the Year 2012}

The ratios that proved to be jointly significant in 2012 at a marginal significance level of 5\% were the following: current assets over total assets, current liabilities over total liabilities, book equity over total assets, fixed assets over total assets, $\log$ of total assets, net income over sales and receivables over total assets. See Appendix C, panel B.

An increase of the ratio of current assets over total assets by 1 unit decreases the odds that the company will be solvent by the exponential of -8.702 , which is close to zero. This negative relationship indicates that the higher the current assets portion of the total assets, the more prone the company is to be subject to non-performing loans. When the company has a relatively high level of receivables and of inventory it may face financial difficulties. High levels of inventory may indicate slow turnover and inability to liquidate stock, and high level of customer debts may indicate problem in collection of credit sales, and a questionable credit policy.

An increase of the ratio current liabilities over total liabilities by 1 unit decreases the odds that the company will be solvent by the exponential of -2.513 , being 0.081 . The higher this ratio is the more prone to financial difficulties the SME will be. The current liabilities are mostly made of trade accounts and bank loans that mature in less than 1 year. In fact, when current liabilities are high compared to total liabilities, the company has a lot of dues to pay during less than 1 year. So the higher the amount of short term debt, the more likely the SME will face financial difficulties.

An increase of the ratio of book equity over total assets by 1 unit increases the odds that the company will be solvent by the exponential of 6.487 , being 656.28 . This signifies that the higher the equity portion of assets the lower the risk of facing financial difficulties, indicating that an SME is better off when it relies on equity financing rather than debt financing.

An increase of the ratio of fixed assets over total assets by 1 unit decreases the odds that the company will be solvent by the exponential of -13.991. A high portion of fixed assets out of total assets indicates a low portion of current assets out of total assets. Thus, this negative relationship means that for a company to be in good shape, it must have a good portion of its assets that can be easily liquidated.

An increase of the ratio of the log of total assets by $1 \%$ increases the odds that the company will be solvent by the exponential of 0.796, being 2.217. This indicates that the bigger an SME is in terms of overall assets, the more prone to solvency and well-performing loans it will be.

An increase of the ratio of net income over sales by 1 unit increases the odds that the company will be solvent by the exponential of 6.51 , being 672 . This signifies that the higher the profitability, the lower the risk of facing financial difficulties.

An increase of the ratio of receivables over total assets by 1 unit decreases the odds that the company will be solvent by the exponential of -4.528 , being 0.011 . This signifies that the higher the receivables portion of assets, the higher the risk of facing financial difficulties. Since receivables are assets that are not cashed in yet, their high level may indicate doubtful accounts and problems in collection.

Eighteen bankrupt companies of the total of 35 bankrupt companies are accurately classified as bankrupt (51.4\%). The remaining 17 are misclassified as solvent. The Type I error is $48.6 \%$. A total of 183 solvent companies out of the total of 187 solvent companies are accurately classified as solvent (97.9\%). The remaining 4 are misclassified as bankrupt. The Type II error is $2.1 \%$. See Table 8 . The overall accuracy percentage is $90.5 \%$, calculated as $(51.4 * 35+97.9 * 187) / 222$. The R-Square is 0.779 : this signifies that $77.9 \%$ of the variation in the dependent variable is explained by the variation in the independent variables. This figure is quite high.

Table 8. Classification of the results of the logistic regression using ratios for the year 2012

\begin{tabular}{llll}
\hline & \multicolumn{1}{c}{ Bankrupt } & \multicolumn{1}{c}{ Non-bankrupt } & Total \\
\hline Bankrupt & $51.4 \%$ (no error) & $48.6 \%$ (Type I) & $100 \%$ \\
Non-bankrupt & $2.1 \%$ (Type II) & $97.9 \%$ (no error) & $100 \%$ \\
\hline
\end{tabular}

\subsubsection{Logistic Regression Based on Average ratios for the Years 2011 and 2012}

The ratios that proved to be jointly significant at a marginal significance level of 5\% in the average of the years 2011 and 2012 were the following: book equity over total assets, working capital over total assets, net income over sales, sales over total assets, and $\log$ of total assets. See Appendix C, panel C. Two additional ratios are found to be significant jointly but insignificant individually: receivables over total assets, and net income over fixed assets. In other words omitting these two variables is not recommendable.

An increase of the ratio of book equity over total assets by 1 unit increases the odds that the company will be solvent by 
the exponential of 3.776, being 43.648. This signifies that the higher the equity relative to total assets (in contrast with the size of liabilities relative to total assets), the lower the risk of facing financial difficulties. This indicates that a company is more prone to solvency when its own funds (capital, retained earnings, annual profit) are adequate.

An increase of the ratio of working capital over total assets by 1 unit increases the odds that the company will be solvent by the exponential of 4.76 , being 116.795 . This signifies that the higher the working capital amount the lower the risk of facing financial difficulties.

An increase of the ratio of net income over sales by 1 unit increases the odds that the company will be solvent by the exponential of 5.866, being 352.973. This signifies that the higher the profitability, the better the financial situation the company will be in and the lower the risk of facing financial difficulties.

An increase of the ratio of sales over total assets by 1 unit increases the odds that the company will be solvent by the exponential of 0.628 , being 1.874 . This signifies that the higher the sales relative to assets, the lower the risk of facing financial difficulties. This indicates that sales must be high enough to cover a significant part of the assets value.

An increase in the log of total assets by 1 percent increases the odds that the company will be solvent by the exponential of 0.647 , being 1.91. This signifies that the higher the total assets amount, the lower the risk of facing financial difficulties.

Out of a total of 35 bankrupt companies 16 bankrupt companies are accurately classified as bankrupt (45.7\%). The remaining 19 are misclassified as solvent (this is the Type I error, being 54.3\%). Out of a total of 187 solvent companies 181 solvent companies are accurately classified as solvent (96.8\%). The remaining 6 are misclassified as bankrupt (this is the Type II error, being $3.2 \%)$. The overall accuracy percentage is $88.7 \%$, calculated as $(45.7 * 35+96.8 * 187) / 222$. See Table 9. The R-Square is 0.508 and signifies that $50.8 \%$ of the variation in the dependent variable is explained by the variation in the independent variables.

Table 9. Classification of the results of the logistic regression using ratios for the average of years 2011 and 2012

\begin{tabular}{|c|c|c|c|}
\hline & Bankrupt & Non-bankrupt & Total \\
\hline Bankrupt & $45.7 \%$ (no error) & $54.3 \%$ (Type I) & $100 \%$ \\
\hline Non-bankrupt & $3.2 \%$ (Type II) & $96.8 \%$ (no error) & $100 \%$ \\
\hline
\end{tabular}

\section{Concluding Remarks}

As stated through the research questions, this study mainly aims to test the applicability of the Altman Z-scores on the SMEs in Lebanon, to identify which financial ratios are the best predictors of the financial state of some chosen companies, and to develop a model that can predict the financial state of a company.

The Altman Z-score models are not very applicable on SMEs in Lebanon. The application of the Altman Z'-score and Z"-score on SMEs in Lebanon shows a modest percentage of accuracy in prediction of bankrupt SMEs as bankrupt despite high accuracy in classifying actually solvent SMEs as solvent, since the Type I error (being the main focus of our study and the most important category) is relatively high in all cases. The Type I error ranges between $31.4 \%$ and $57.1 \%$. Accordingly, the models' accuracy percentage in the classification of bankrupt companies as bankrupt is relatively low, and ranges between $25.7 \%$ and $40 \%$. As for the solvent SMEs, the Altman models are able to accurately classify $67.4 \%$ to $94.1 \%$ of the sample. This results in a relatively low Type II error.

Some of an SME's financial ratios are individually significant. The financial ratios that proved to be significant during 2011, 2012, and the average of both years are the following: liabilities over total assets, liquid assets over current assets, sales over liabilities, and working capital over total assets. Other variables proved to be significant in a specific year and/or in the average of the two years.

The logistic regression models are also not very applicable on SMEs in Lebanon. The logistic regression models does not result in high accuracy levels in the prediction of bankrupt companies as being bankrupt, resulting in a high Type I error. However, the models do achieve high accuracy levels in the prediction of solvent companies as being solvent. The model that achieves the best results is the 2012 model, which is able to classify $97.9 \%$ of the actually solvent companies as solvent, leading to a Type II error of $2.1 \%$. However, this model accurately classifies only $51.4 \%$ of the bankrupt companies as bankrupt, resulting in a high Type I error of $48.6 \%$.

The ratios that proved to be jointly significant in the logistic regression models are different from the variables which constitute the Altman Z-score models. In the year 2011, two ratios constituted the logistic regression model and were both part of the Altman models. In the year 2012, the developed model included none of the Altman models components. For the average of the years 2011 and 2012, the developed logistic model which is constituted by seven variables, included two of the Altman models components, being the working capital over total assets and the sales over total assets. 
From the above study and findings, we can conclude that it is difficult to predict bankruptcy in Lebanon using only quantitative data (being financial ratios).

Although the Altman models and the developed logistic regression models attain high accuracy levels in predicting the healthy state of solvent companies, they fail to achieve high accuracy results in the prediction of the bankrupt state of financially unhealthy companies, which is the aim of credit risk management, Thus, it can be concluded that models using only quantitative data cannot predict which SMEs will be subject to non-performing loans in Lebanon. A more comprehensive view of the business through taking into consideration qualitative data concerning the management of the company, the succession preparation, the banking history, and the legal history can yield to a better analysis, assessment and prediction of a company's financial state.

Another conclusion is that some financial ratios are worth focusing on when assessing a company's financial health, since they significantly differ between a solvent company and a bankrupt company. The ratio of liabilities over total assets is lower for solvent companies. In fact the average of this ratio for the solvent companies is around 0.28 , while it reaches 0.58 for bankrupt companies. For the ratio of liquid assets over current assets, it is lower for a solvent company compared to a bankrupt company, reaching an average 0.45 for the former and 0.57 for the latter. As for sales over liabilities, it is higher for solvent companies relative to bankrupt companies, evidenced by the average of 12.16 for healthy companies and 2.79 for unhealthy companies. The working capital over total assets ratio is higher for a solvent company than for a bankrupt company, where the average for the former is 0.27 and is 0.06 for the latter.

In summary, in order to have a good assessment of a client, many factors must be taken into consideration. When analyzing the financials, the ratios stated above should be considered, after a global view of the balance sheet, income statement and cash flow statement. The business as a whole should be viewed in an objective manner, considering the macroeconomic conditions in the region, such as the economy of the country, the political situation, the setting of the industry to which the business belongs to and other factors of influence.

\section{References}

Alareeni B., \& Branson J. (2013). Predicting listed companies' failure in Jordan using Altman models: a case study. International Journal of Business and Management, 8(1), 113-126. http://dx.doi.org/10.5539/ijbm.v8n1p113

Alkhatib, K., \& Al Bzour, A. E. (2011). Predicting corporate bankruptcy of Jordanian listed companies: using Altman and Kida models. International Journal of Business and Management, 6(3), 208-215. http://dx.doi.org/10.5539/ijbm.v6n3p208

Altman, E., Danovi, A., \& Falini, A. (2013). Z-score models' application to Italian companies subject to extraordinary administration. Journal of Applied Finance, 23(1), 128-137.

Altman, E. (1993). Corporate financial distress and bankruptcy, 2nd edition. New York: John Wiley \& Sons.

Altman, E. (2002). Bankruptcy, credit risk and high yield junk bonds. Malden, MA: Blackwell.

Altman, E. I. (1968). Financial ratios, discriminant analysis and the prediction of corporation bankruptcy. The Journal of Finance, 23, 589-609. http://dx.doi.org/10.1111/j.1540-6261.1968.tb03007.x

Berzkalne, I., \& Zelgalve, E. (2013). Bankruptcy prediction models: a comparative study of the Baltic listed companies. Journal of Business Management, 7, 72-82.

Bordeianu, G. D., Radu, F., Paraschivescu, M. D., \& Pãvãloaia, W. (2011). Analysis models of bankruptcy risk. Economy Transdisciplinarity Cognition, 14(1), 248-259.

Gerantonis, N., Vergos, K., \& Christopoulos, A. G. (2009). Can Altman Z-score models predict business failures in Greece? Research Journal of International Studies, 12, 21-28.

Grice, J. S., \& Ingram, R. W. (2001). Test of generalizability of Altman's bankruptcy prediction model.Journal of Business Research, 10, 53-61. http://dx.doi.org/10.1016/S0148-2963(00)00126-0

Hillegeist, S. A., Keating, E. K., Cram, D. P., \& Lundstedt, K. G. (2004). Assessing the probability of bankruptcy. Review of accounting studies, 9(1), 5-34. http://dx.doi.org/10.1023/B:RAST.0000013627.90884.b7

Kovács, I., Dóczi, H., Erdély, A., Felfalusi, E., Knoch, R. K., \& Patka, K. E. (2011). Overview of the relevant indicators of defaulted and non defaulted companies and possibilities of improvement for the rating systems used by the Romanian commercial banks. European Integration-New Challenges, 1126, 413-418.

Li, J. (2012). Prediction of corporate bankruptcy from 2008 through 2011. Journal of Accounting \& Finance, 12(1), 31-41.

Li, J., \& Rahgozar, R. (2012). Application of the Z-score model with consideration of total assets volatility in predicting 
corporate financial failures from 2000-2010. Journal of Accounting and Finance, 12(2), 11-19.

Lugovskaya, L. (2010). Predicting default of Russian SMEs on the basis of financial and non-financial variables. Journal of Financial Services Marketing, 14(4), 301-313. http://dx.doi.org/10.1057/fsm.2009.28

Onofrei, M., \& Lupu, D. (2014). The modeling of forecasting the bankruptcy risk in Romania. Economic Computation \& Economic Cybernetics Studies \& Research, 48(3), 197-215.

Samkin, G., Low, M., \& Adams, T. (2012). The use of Z-scores to predict finance company collapses: a research note. New Zealand Journal of Applied Business Research, 10(2), 69-82.

Sirirattanaphokun,W., \& Pattarathammas, S. (2012). Default prediction for small-medium enterprises in emerging market: evidence from Thailand. Seoul Journal of Business, 18, 2, 25-54.

Strobel, F. (2011). Bank insolvency risk and different approaches to aggregate Z-score measures: a note. Applied Economics Letters, 18(6), 1541-1543. http://dx.doi.org/10.1080/13504851.2010.548775

Wang, Y., \& Campbell, M. (2010). Business Failure Prediction for Publicly Listed Companies in China. Journal of Business and Management, 16, 75-88.

Waszkowski, A. (2011). Methods of classification models for enterprises insolvency prediction. Acta Scientiarum Polonorum, 95-106.

\section{Appendix A: The Models}

Altman Z'-score: Z'=0.717X1 + 0.847X2 + 3.107X3 + 0.420X4 + 0.998X5

$\mathrm{X} 1=$ Working capital over total assets

$\mathrm{X} 2=$ Retained earnings over total assets

$\mathrm{X} 3=$ Earnings before interest and taxes over total assets

$\mathrm{X} 4$ = Book value of equity over total liabilities

X5 $=$ Sales over total assets

The score values are interpreted as follows:

$>2.90=$ Tend not to fail

$1.23-2.90=$ Grey area

$<1.23=$ Tend to fail

Altman Z"-score: Z" = 6.56 X $1+3.26$ X2 + 6.72 X3 + 1.05 X4

$\mathrm{X} 1$ : Working capital over total assets

$\mathrm{X} 2$ : Retained earnings over total assets

$\mathrm{X} 3$ : Earnings before interest and taxes over total assets

$\mathrm{X} 4$ : Book value of equity over total liabilities

The score values are interpreted as follows:

$>2.90=$ Tend not to fail

$1.23-2.90=$ Grey area

$<1.23=$ Tend to fail

\section{Appendix B: The Financial Ratios and Indicators Selected}

Net income over book equity

Liabilities over book equity 
Book equity over fixed assets

Current assets over total assets

Net income over fixed assets

Liquid assets over current assets

Working capital over total assets

Retained earnings over total assets

Earnings before interest and taxes over total assets

Book value of equity over total liabilities

Sales over total assets

Current assets over current liabilities,

Current liabilities over book equity

Total liabilities over total assets

Book equity over total assets

Sales over current assets

Net income over Sales

Log of total assets

Current liabilities over total liabilities

Receivables over total assets

Fixed assets over total assets

Sales over total liabilities

\section{Appendix C: Logistic Regressions}

Panel A: Logistic regression for the year 2011: Variables in the Equation

\begin{tabular}{lcccccc} 
Variables in the Equation & B & S.E. & Wald & df & Sig. & $\operatorname{Exp}(\mathrm{B})$ \\
\hline $\begin{array}{l}\text { Book value of equity } \\
\text { value of total liabilities }\end{array}$ & .320 & .107 & 8.896 & 1 & .003 & 1.377 \\
Working capital over total assets & 2.256 & .882 & 6.549 & 1 & .010 & 9.549 \\
constant & .310 & .306 & 1.026 & 1 & .311 & 1.363 \\
\hline
\end{tabular}

Panel B: Logistic regression for the year 2012:

\begin{tabular}{|c|c|c|c|c|c|c|}
\hline \multicolumn{7}{|l|}{ Variables in the Equation } \\
\hline & B & S.E. & Wald & $\mathrm{df}$ & Sig. & $\operatorname{Exp}(B)$ \\
\hline Current assets over total assets & -8.702 & 4.133 & 4.432 & 1 & .035 & .000 \\
\hline Current liabilities over total liabilities & -2.513 & 1.029 & 5.962 & 1 & .015 & .081 \\
\hline Book equity over total assets & 6.487 & 1.229 & 27.835 & 1 & .000 & 656.279 \\
\hline Fixed assets over total assets & -13.991 & 4.358 & 10.308 & 1 & .001 & .000 \\
\hline Log of total assets & .796 & .300 & 7.049 & 1 & .008 & 2.217 \\
\hline Net income over sales & 6.510 & 2.246 & 8.400 & 1 & .004 & 672.000 \\
\hline Total receivables over total assets & -4.528 & 2.007 & 5.091 & 1 & .024 & .011 \\
\hline
\end{tabular}

Panel C: Logistic regression for the averages of year 2011 and 2012:

\section{Variables in the Equation}

Book equity over total assets

Working capital over total assets

Net income over sales

Sales over total assets

Log of total assets

Receivables over total assets

Net income over fixed assets

Constant

$\begin{array}{lll}\text { B } & \text { S.E. } & \text { Wald } \\ 3.776 & 1.089 & 12.019 \\ 4.760 & 1.409 & 11.410 \\ 5.866 & 2.265 & 6.707 \\ .628 & .329 & 3.648 \\ .647 & .244 & 7.010 \\ -3.550 & 2.408 & 2.173 \\ -.020 & .013 & 2.609 \\ -11.450 & 3.600 & 10.118\end{array}$

Sig.

$.001 \quad 43.648$

$.001 \quad 116.795$

$.010 \quad 352.973$

$.056 \quad 1.874$

$.008 \quad 1.910$

$.140 \quad .029$

$106 \quad .980$

$.001 \quad .000$

\section{(cc) $\mathrm{Br}$}

This work is licensed under a Creative Commons Attribution 3.0 License. 